\title{
PELATIHAN MANAJEMEN PENGELOLAAN BUMDes Mart KECAMATAN AIKMEL KABUPATEN LOMBOK TIMUR
}

\author{
Khosiah $^{1}$ dan Sintayana Muhardini ${ }^{2}$ \\ Universitas Muhammadiyah Mataram \\ osynasdem01@gmail.com
}

\begin{abstract}
Abstrak
Managemen adalah sebuah proses untuk mengatur sesuatu yang dilakukan oleh sekelompok orang atau organisasi untuk mencapai tujuan organisasi tersebut dengan cara bekerjasama memanfaatkan sumberdaya yang dimiliki. Badan Usaha Milik Desa (BUMDes) merupakan salah satu program strategis pemerintah dalam upaya meningkatkan kesejahteraan ekonomi masyarakat yang ada di pedesaan. BUMDes juga bisa berperan sebagai pengelola keuagan inklusif seperti usaha simpan pinjam yang bila dikelola dengan baik, bisa meningkatkan pendapatan yang cukup baik. BUMDes bisa menjadi sarana pembayaran maupun pemmbiayaan, seperti pembayaran air, listrik dan lain-lainnya. Secara garis besar BUMDes mrmiliki dua manfaat, yaitu komersil dan pelayanan publik. Sehingga dengan terbentuk Badan Usaha Milik Desa (BUMDes) diharapkan desa bisa lebih mandiri dengan memajukan unit-unit usaha lainnya dalam wadah BUMDes. Adapun tujuan pelatihan ini adalah a) Memfasilitasi peningkatan kapasitas desa untuk mewujudkan replikasi atau adopsi kegiatan inovasi desa; b) Meningkatkan kapasitas kelembagaan Pengurus BUMDes Mart dalam rangka pemenuhan kebutuhan layanan sosial dasar masyarakat desa. Metode yang digunakan dalam pelatihan ini adalah metode ceramah, tanya jawab dan metode diskusi. Berdasarkan hasil pelatihan menunjukkan bahwa para peserta sudah mampu melakukan manajemen dan pengelolaan terhadap unit-unit usaha yang ada di Desa masing-masing, ini terlihat dari pedampingan yang dilakukan oleh narasumber.
\end{abstract}

\section{Kata Kunci : Management, Pengelolaan, Bumdes Mart}

\section{PENDAHULUAN}

Managemen adalah sebuah proses untuk mengatur sesuatu yang dilakukan oleh sekelompok orang atau organisasi untuk mencapai tujuan organisasi tersebut dengan cara bekerjasama memanfaatkan sumberdaya yang dimiliki. Secara etimologi kata Manajemen diambil dari bahasa Prancis Kuno, yaitu Managemnt yang artinya adalah seni dalam mengatur dan melaksanakan. Management juga dapat diartikan sebagai upaya perencanaan, pengkoordinasian, pengorganisasian, dan pengontrolan sumberdaya untuk mencapai sasaran seacara efisien dan efektif. Efektif dalam hal ini adalah untuk mencapai tujuan sesuai perencanaan dan efisien untuk melaksanakan pekerjaan dengan benar dan terorganisir. Badan Usaha Milik Desa (BUMDes) merupakan salah satu program strategis pemerintah dalam upaya meningkatkan kesejahteraan ekonomi masyarakat yang ada di pedesaan. BUMDes juga bisa berperan sebagai pengelola keuagan inklusif seperti usaha simpan pinjam yang bila dikelola dengan baik, bisa meningkatkan pendapatan yang cukup baik. BUMDes bisa menjadi sarana pembayaran maupun pemmbiayaan, seperti pembayaran air, listrik dan lainlainnya. Secara garis besar BUMDes mrmiliki dua manfaat, yaitu komersil dan pelayanan publik. Sehingga dengan terbentuk Badan Usaha Milik Desa (BUMDes) diharapkan desa bisa lebih mandiri dengan memajukan unit-unit usaha lainnya dalam wadah BUMDes.

\section{Tujuan}

Adapun tujuan diadakannya pelatihan ini adalah:

1. Memfasilitasi peningkatan kapasitas desa untuk mewujudkan replikasi atau adopsi kegiatan inovasi desa.

2. Meningkatkan kapasitas kelembagaan Pengurus BUMDes Mart dalam rangka 
pemenuhan kebutuhan layanan sosial dasar masyarakat desa.

\section{Manfaat}

Adapun manfaat dari pelaksanaan pelatihan ini adalah :

1. Dapat meningkatkan kapasitas para pengurus BUMDes terutama BUMDes Mart serta unit-unit usaha lainnya yang bernaung dalam wadah Badan Usaha Milik Desa (BUMDes).

2. Sebagai pedoman bagi Pengurus BUMDes Mart dalam manajemen pengelolaan unitunit usaha yang ada dalam Badan Usaha Milik Desa (BUMDes).

\section{METODE PELAKSANAAN}

Metode merupakan cara yang dilakukan dalam melakukan kegiatan pelatihan supaya kegiatan pelatihan lebih terarah. Adapun metode yang dilakukan dalam pelatihan ini yakni :

1. Metode Ceramah

Metode ceramah adalah penyajian informasi secara lisan baik yang formal maupun informal. Metode ceramah ini dilakukan untuk menjelaskan materi kepada peserta peatihan kaitannya dengan bagaimana mengelola unit-unit usaha yang ada di desa masing-masing terutama Badan Usaha Milik Desa (BUMDes).

\section{Metode Diskusi}

Metode diskusi merupakan suatu metode pengajaran dimana para pelatih memberikan suatu persoalan atau masalah kepada peserta pelatihan yang kemudian sama-sama dibahas untuk mencari solusi permasalahnnya serta dalam metode diskusi ini para peserta pelatihan bisa mengemukakan permasalahan yang dialami dalam unit usaha masing-masing untuk dibahas dan dicari solusinya.

3. Metode Dokumentasi

Metode dokumentasi adalah salah satu metode pengumpulan data kualitatif dengan melihat atau menganalisis dokumen yang sudah dibuat.

Jadi dalam pelatihan ini mendokumentasikan segala kegiatan yang dilakukan oleh pelatih dan para peserta pelatihan BUMDes Mart Kecamatan Aikmel dan Lenek Kabupaten Lombok Timur.

\section{PENYELENGGARAAN KEGIATAN}

\section{Waktu dan Tempat Kegiatan}

Waktu pelaksanan pelatihan yakni pada hari Senin-Selasa Tanggal 23-24 Desember 2019. Adapun tempat pelaksanaan kegiatan yakni di Aula Kantor Camat Aikmel. Peserta dalam pelatihan ini adalah 7 Desa yang memang memiliki BUMDes Mart, yakni :

1. Desa Kembangkerang

2. Desa Toya

3. Desa Aikmel

4. Desa Kalijaga

5. Desa Kalijaga Tengah

6. Desa Sukarema

7. Desa Lenek Baru

Waktu : Hari Senin-Selasa, Tanggal 23-24 Desember 2019

$\begin{aligned} \text { Tempat }:> & \text { Aula Kantor Camat } \\ & \text { Aikmel } \\ \text { Peserta }:> & \text { Katua BUMDes Mart } \\ & \text { dan Ketua Unit Usaha } \\ & \text { Lainnya yang ada di } \\ & \text { Desa masing-masing }\end{aligned}$

\section{HASIL DAN PEMBAHASAN}

\section{Hasil Kegiatan}

Adapun data peserta Pelatihan Manajemen Pengelolaan BUMDes Mart Kecamatan Aikmel, yakni dapat dilihat pada Tabel 01 berikut.

Tabel 01. Data Peserta Pelatihan SeKecamatan Aikmel-Lenek

\begin{tabular}{|l|l|l|}
\hline No. & \multicolumn{1}{|c|}{ Nama Peserta } & \multicolumn{1}{c|}{ Alamat } \\
\hline 1 & Munawir Sadzari & Bumdes Sukarema \\
\hline 2 & Mariati & Bumdes Sukarema \\
\hline 3 & M. Kamarudin & $\begin{array}{l}\text { Bumdes } \\
\text { Kembangkerang }\end{array}$ \\
\hline 4 & Zaenul M & $\begin{array}{l}\text { Bumdes } \\
\text { Kembangkerang }\end{array}$ \\
\hline 5 & Nasoan & $\begin{array}{l}\text { Bumdes } \\
\text { Kembangkerang }\end{array}$ \\
\hline 6 & Siti Ziadah & Bumdes Lenek Baru \\
\hline 7 & Layla Hauri & Bumdes Lenek Baru \\
\hline 8 & $\begin{array}{l}\text { Huswatun } \\
\text { Hasanah }\end{array}$ & $\begin{array}{l}\text { Bumdes } \\
\text { Tengah }\end{array}$ \\
\hline 9 & Kartini & $\begin{array}{l}\text { Bumdes } \\
\text { Tengah }\end{array}$ \\
\hline 10 & Sunardi & Bumdes Lkm Kalijaga \\
\hline 11 & L. Abdul Bais & Pamdes Kalijaga \\
\hline 12 & M. Zakirin & Bumdes Toya \\
\hline 13 & Jalaludin & Bumdes Toya \\
\hline 14 & Syahrial & Bumdes Aikmel \\
\hline
\end{tabular}

(Sumber : Olahan, 2019) 
Dokumentasi Kegiatan

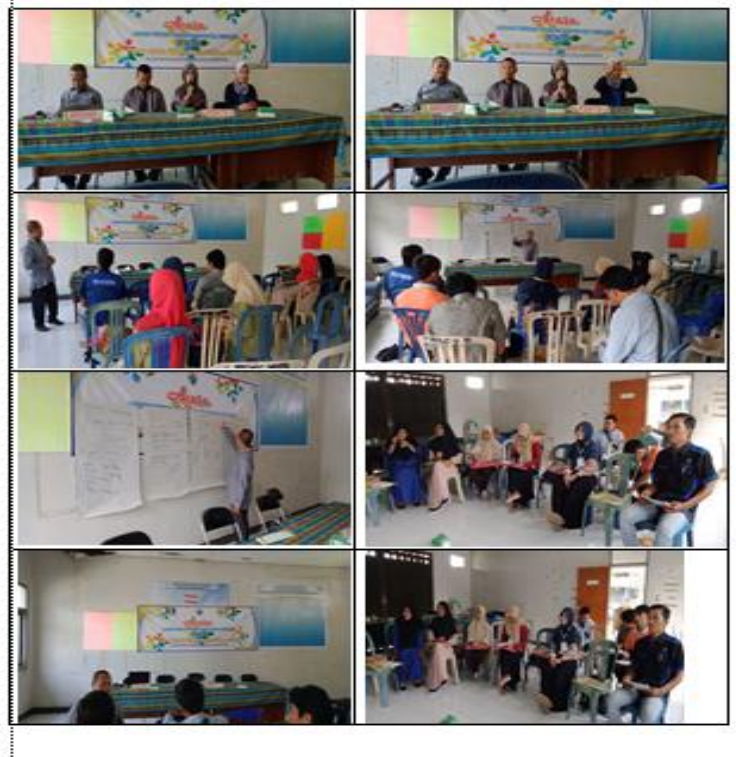

2. Pembahasan

Dalam pelatihan yang dilakukan kami melakukan kajian dan identifikasi kebutuhan layanan Peningkatan Kapasitas Teknik Desa (P2KTD) dan terdapat 7 Desa yang memang sangat membutuhkan layanan P2KTD tersebut.

Pada saat pelaksanaan Pelatihan para peserta sangat antusias sekali mengikuti semua materi yang dsajikan oleh narasumber. Yang mana para peserta bisa membahas segala persoalan yang mereka hadapi dalam menjalankan usaha-usaha yang ada di Desa masingmasing.

Pengertian Managemen adalah sebuah proses untuk mengatur sesuatu yang dilakukan oleh sekelompok orang atau organisasi untuk mencapai tujuan organisasi tersebut dengan cara bekerjasama memanfaatkan sumberdaya yang dimiliki. Secara etimologi kata Manajemen diambil dari bahasa Prancis Kuno, yaitu Managemnt yang artinya adalah seni dalam mengatur dan melaksanakan. Management juga dapat diartikan sebagai upaya perencanaan, pengkoordinasian, pengorganisasian, dan pengontrolan sumberdaya untuk mencapai sasaran seacara efisien dan efektif. Efektif dalam hal ini adalah untuk mencapai tujuan sesuai perencanaan dan efisien untuk melaksanakan pekerjaan dengan benar dan terorganisir. Pada saat pelatihan Para peserta melakukan kajian terhadap unit usaha yang ada di BUMDES masing-masing dan mencari solusinya apabila ditemukan ada masalah dalam pengelolaannya. Kesulitan yang banyak dialami oleh para peserta yakni dalam menghitung rumus biaya pemesanan dengan biaya penyimpanan yakni pada Rumus Economic Order Quantity (EOQ). Hal ini dikarenakan selama menjalankan unit usahanya tidak pernah menggunakan rumus ekonomi hanya dengan cara biasa, dengan adanya pelatihan ini dapat meningkatkan pengetahuan para pengurus atau pengelola BUMDes yang ada di desa masing-masing.

\section{A. PENUTUP}

\section{Simpulan}

Pengertian Managemen adalah sebuah proses untuk mengatur sesuatu yang dilakukan oleh sekelompok orang atau organisasi untuk mencapai tujuan organisasi tersebut dengan cara bekerjasama memanfaatkan sumberdaya yang dimiliki. Badan Usaha Milik Desa (BUMDes) merupakan salah satu program strategis pemerintah dalam upaya meningkatkan kesejahteraan ekonomi masyarakat yang ada di pedesaan. BUMDes juga bisa berperan sebagai pengelola keuagan inklusif seperti usaha simpan pinjam yang bila dikelola dengan baik, bisa meningkatkan pendapatan yang cukup baik, oleh karena diperlukan pengetahuan yang memadai dalam mengelola dan memenej unit-unit usaha yang ada di BUMDes, terutama unit usaha BUMDes Mart.

\section{Saran}

Perlu adanya perhatian khusus dan Pendampingan bagi Desa supaya lebih terarah di dalam memenej pengelolaan usaha-usaha yang ada di Desa Masing-masing.

\section{B. DAFTAR PUSTAKA}

Kaswan. 2012. Manajemen Sumber Daya Manusia untuk Keunggulan Bersaing Organisasi. Graha Ilmu, Yogyakarta

Rosidah, Ambar Teguh S. 2009. Manajemen Sumber Daya Manusia Konsep Teori dan Pengembangan Dalam Konteks Organisasi Publik. Graha Ilmu, Yogyakarta

www.maxmanroe.co 